\title{
Formation methods of hybrid urban spaces in the historic city center
}

\author{
Elena Zaykova*
}

Moscow State University of Civil Engineering, Yaroslavskoe shosse, 26, Moscow, 129337, Russia

\begin{abstract}
Russian urban planning practice is experiencing an era of global changes. The appearance of architectural and landscape objects with different types of organization of public spaces in Moscow makes it possible to talk about the transition from standard city planning to objects that have no boundaries between nature, architecture and human environment. Functionally renewed Gorky Park with Crimean Quay and Zaryadye Park represent a new type of public space where nature and technology, education and entertainment, history and modernity are combined and complement each other. New objects have a positive effect on environmental changes using the latest construction technologies, offer citizens a variety of activities and have a powerful scientific resource in working on city aesthetics and ecology. Scientists describe such townplanning objects, as "hybrid spaces". Hybridization of urban areas encompasses different urban planning levels: from integration of architectural landscape object with border elimination by nature in the historic city center (Zaryadye Park) to formation of the newest linear park with different types of public in the contour of the water area (Gorky Park and Crimean Quay). Due to the high interest of professionals in the new city objects, hybrid spaces deserve to be thoroughly studied, as they influence not only quality of urban environment in the use of landscape architecture tools and technologies, but also issues of managing urbanization and climate change in the near future.
\end{abstract}

\section{Introduction}

Issues of architecture hybridization and landscape are not studied in Russia. In scientific literature issues of preservation of natural components and sites of the nature in structure of urban areas $[4,16]$ on the principles of sustainability [5], city regeneration [1], renovation of residential quarters in a contour of water areas [2] are discussed with different types of social activity [3]. The questions of territories sustainable development are considered from a position of landscaping and reconstruction of different types of city spaces $[8,9]$ on the principles of sustainable urbanism [7]. Therefore, search of new model of development of the cities where the typology of a landscape and nature components are means not only identities, but also flexibility of the environment in the new town-planning idea $[9,10,11]$ is necessary. It is necessary to add to it that the increasing risks on the planet from floods,

\footnotetext{
*Corresponding author: lena_landscape21@mail.ru
} 
hurricanes, the fires and droughts force experts not only to adapt to these changes and to learn to control them, but also to seize new technologies and approaches in design $[6,17$, 18]. The presented arguments help us to look at a new way of hybridization processes between building and Environment using the new green technologies for sustainable territories development nowadays and for the benefit of future generations. Therefore, the subject of this article is of interest for a wide range of professionals.

\section{Methods}

The purpose of this work is comprehensive study of examples from the world design practice of multipurpose hybrid architectural and landscape objects and the definition of their typological characteristics. Research problems include the judgment of the theory of space hybridization between the building and Environment in comparison with the Zaryadye park and the historic center of the city. The last one has many typological properties of new hybrid space and is a striking example for forecasting and development of hybrid models in the Russian cities.

The analysis of modern world practice of multipurpose hybrid architectural and landscape projects allows to draw the first conclusions of integration methods of components of the nature and new technologies in changing of facades and roofs construction, extra architectural space in its environment. Therefore, in the future such objects will be of interest to town-planners, architects, landscape architects, ecologists and climatologists. During creation of new strategies of development for urban territories the natural and social environment in the conditions of post-industrial reality and the progressing urbanization is that component of spatial development of the cities which needs to be adapted and filled carefully at the different town-planning levels [7].

In this regard multipurpose hybrid architectural and landscape objects are of such interest to experts in terms of design decisions, social and cultural programming and communications on a vertical and a horizontal of architecture with the nature and a landscape [18]. Modern examples of similar approach are the Fukuoka Prefectural International Hall projects (Japan) [11], Stadthaus M1 is false-frameworks (Freiburg, Germany) [17], Bosco Verticale (Milan, Italy) [12], the central Bicentenario Park (Bogota), Hortus-Urbanism (China), Alcázar de Toledo (Mexico City) and a lot of others.

They show us the new types of multipurpose hybrid architectural and landscape objects where the planning element has the function, technology of the nature components integration in front space of the building, planning depending on placement and function in city fabric, the social scenario for different age groups. Functional filling includes recreational, sports and communicative components in the structure of a complex territory.

Such objects render the strongest esthetic, ecological and economic influence on adjacent territories, change ratios between the nature and architecture, technologies of construction and city structures, promote to increase an economic territories profitability in a surrounding of a hybrid object. The examples given above became a basis for comprehensive study and adaptation to the Russian town-planning practice, gained new development in the strategy of formation of different types of the hybrid urbanized spaces in Russia. First of all, Zaryadye park having signs of hybridization of space in the historic center of the city concerns them.

As a first approximation all implemented projects with hybrid properties can be divided into six main groups depending on a way of integration of natural components into their structure: as a part of architecture, frameworks on facades and in an internal contour of the building, the building - the forest, the Green Bridge as the shelter of an engineering and transport object, landscape as connecting fabric between hybrid objects (table 1) [14-15]. 
Table 1. Typological features of different types of hybrid architectural and landscape objects depending on a way of natural components integration

\begin{tabular}{|c|c|c|c|}
\hline № & $\begin{array}{c}\text { Integration } \\
\text { Types }\end{array}$ & Schemes & $\begin{array}{c}\text { DEVELOPMENT } \\
\text { TRENDS } \\
\end{array}$ \\
\hline 1 & $\begin{array}{c}\text { In a part of a } \\
\text { building }\end{array}$ & Green roof "flowing" on the level 0 & $\begin{array}{l}\text { The change of green } \\
\text { roofs` design, creation } \\
\text { of gardening on } \\
\text { different marks for } \\
\text { division of object } \\
\text { levels into different } \\
\text { functional zones }\end{array}$ \\
\hline 2 & $\begin{array}{l}\text { Frameworks } \\
\text { on facades } \\
\text { and in an } \\
\text { internal } \\
\text { contour of the } \\
\text { building }\end{array}$ & $\begin{array}{c}\text { Frameworks on a facade and in an internal contour } \\
\text { of the building }\end{array}$ & $\begin{array}{l}\text { Possibility to organize } \\
\text { by means of } \\
\text { frameworks of } \\
\text { different functional } \\
\text { zones and } \\
\text { compensating } \\
\text { gardening }\end{array}$ \\
\hline 3 & $\begin{array}{c}\text { Wood } \\
\text { Building }\end{array}$ & Nature components in a front space of the building & $\begin{array}{c}\text { Housing and } \\
\text { recreation in a natural } \\
\text { environment will } \\
\text { demand revision of } \\
\text { buildings and facades } \\
\text { design }\end{array}$ \\
\hline 4 & $\begin{array}{c}\text { The Green } \\
\text { Bridge is the } \\
\text { shelter of an } \\
\text { engineering } \\
\text { and transport } \\
\text { object }\end{array}$ & $\begin{array}{c}\text { Communication between landscapes through a } \\
\text { multipurpose hybrid object }\end{array}$ & $\begin{array}{c}\text { Integration of an } \\
\text { engineering transport } \\
\text { object with an adjacent } \\
\text { landscape, noise } \\
\text { reduction }\end{array}$ \\
\hline
\end{tabular}




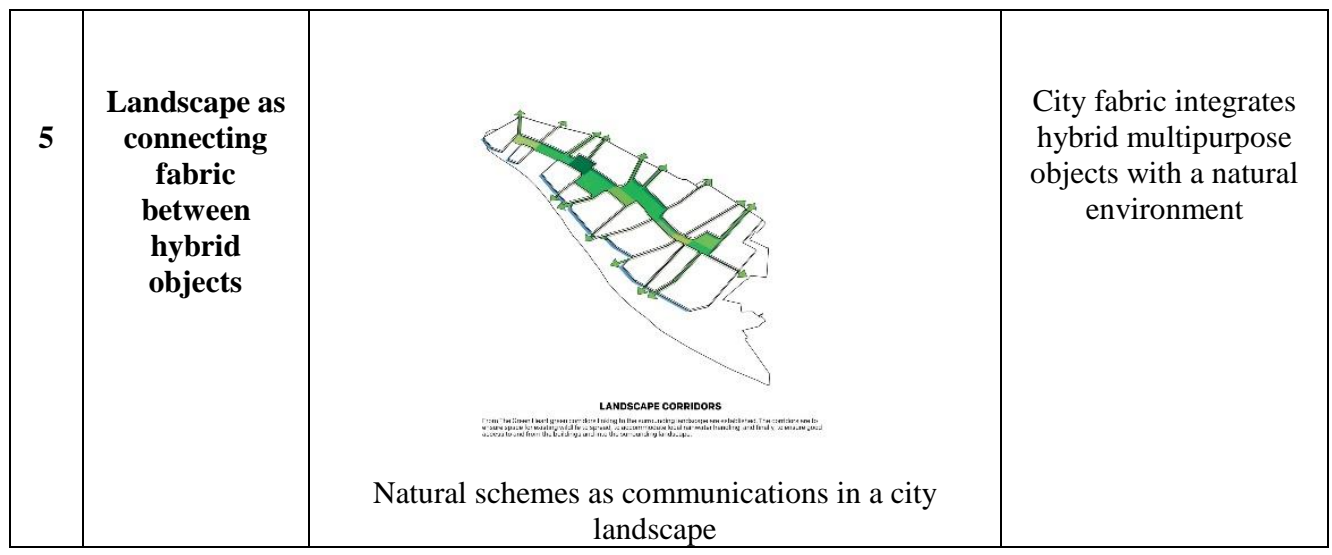

Comparing typological features to presented world projects, it is possible to tell with confidence about space hybridization and structures of buildings in Zaryadye park. Due to such integration we received an object with unique properties in historic center of Moscow. The architecture is solved in such a way that integrates green technologies of surfaces of roofs, facades with the organization of huge geoplasticity in a contour of buildings. The effect of huge architectural and green hills creates feeling of chamber space with extended transit and different specific points on heights. The most important thing is a new image of the city in its historic center as the place of attraction and meetings.

\section{Results}

Typological features of different types of hybrid architectural and landscape objects depending on a way of integration of natural components are presented in table 1. All groups have certain signs which Zaryadye park has also. First of all, the new signs set transformation of building surfaces with green technologies integration.

They treat technologies of sustainable territories development and can influence to change an esthetic and ecological situation in the historic city center. The absence of extra architectural spaces in the downtown can be compensated by use of a landscape as connecting fabric between hybrid objects. On the example of Zaryadya park it is possible to offer the following methods of formation of hybrid spaces in the historic city center.

To overcome the shortage of natural spaces in the central part of Moscow and change the ratio of the built-up to nature in favor of the nature, and also increase the level of comfort and environmental indicators of a particular place, there are the appropriate methods for quality improvements in an urban structure.

Method of economic feasibility (attractiveness) is to increase the green surfaces in buildings' structure in order to cover expenditures, change of image as well as industrial areas' social attractiveness for all kinds of activities.

Method of "flowing" surfaces is to select those materials and technologies that provide the modern trends of industrial areas renovation. The method is especially relevant in the central part of the city to provide "green" features of industrial architecture interior with the exterior of the building and adjacent area by means of landscaped surfaces.

The method of facades transformation suggests an increase in vertical and horizontal surfaces with green components and their coherence with other elements of a green framework and green infrastructure of the city. The central part key problem remains the 
lack of roof gardening. Medium and low-rise buildings are preserved in city's historic center. The basic requirement of the green technology is to integrate the surface into the surrounding architectural landscape through the reconstruction of old buildings or the integration of new innovative buildings, considering area historicity, operation convenience and modern engineering directions. This will help to equip thousands of square meters of roof surfaces and to compensate the lack of outside architectural spaces in built-up area. The experience of Scandinavian colleagues illustrates the opportunities of landscaping, roof maintenance for harsh climate countries, all seasons surface decoration and city life quality improvement (Fig. 1).

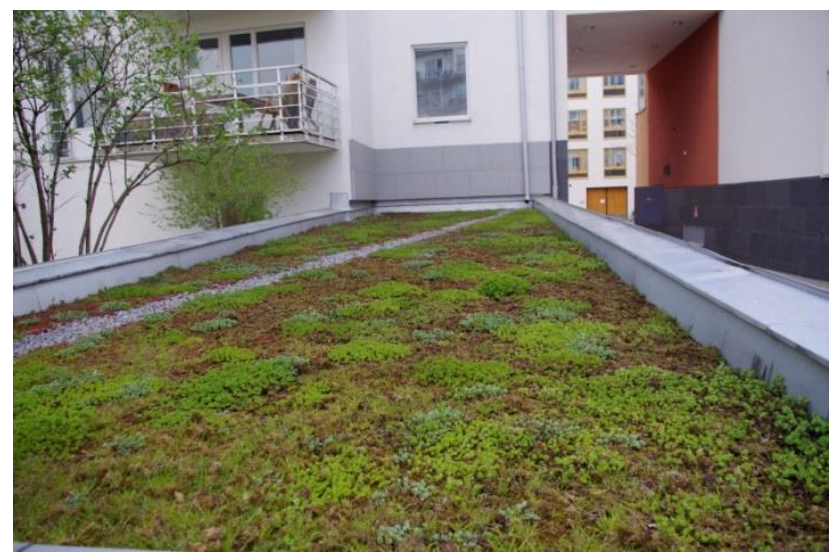

Fig. 1. Operated underground parking roof with easy care plants in the yard area of Hammar by Sjostad residential area in Stockholm, Sweden [photo by author].

The method of false-frames integration is used for the reconstruction and restoration of historical and cultural heritage constructions to ensure the "life" of old constructions in new socio-economic and environmental conditions. The creation of false-facades is particularly relevant in reconstruction and restoration of historical and cultural heritage constructions. These technologies are extremely important for industrial areas renovation in the central historical part, and also provide new surfaces images in industrial architecture. For example, the dwelling reconstruction in Konstanz by compensatory vertical gardening, uniting the building with the environment. Such method is relevant to harsh climate countries, as Russia (Fig 2).

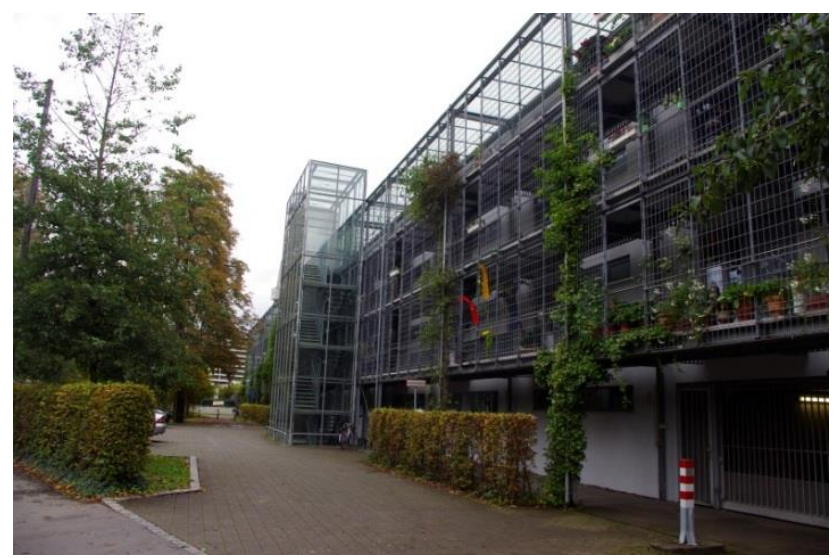

Fig. 2. The dwelling reconstruction with the false facade for vertical gardening - Konstanz, Germany [photo by author]. 
These technologies provide urban built-up environment with aesthetic indicators, enabling this part of the city to function as a "sustainable body" in the structure of the urban fabric, providing locally social and environmental stability in a particular place [4] (table 2).

Table 2. Methods of a town-planning improvement in the central part of the city

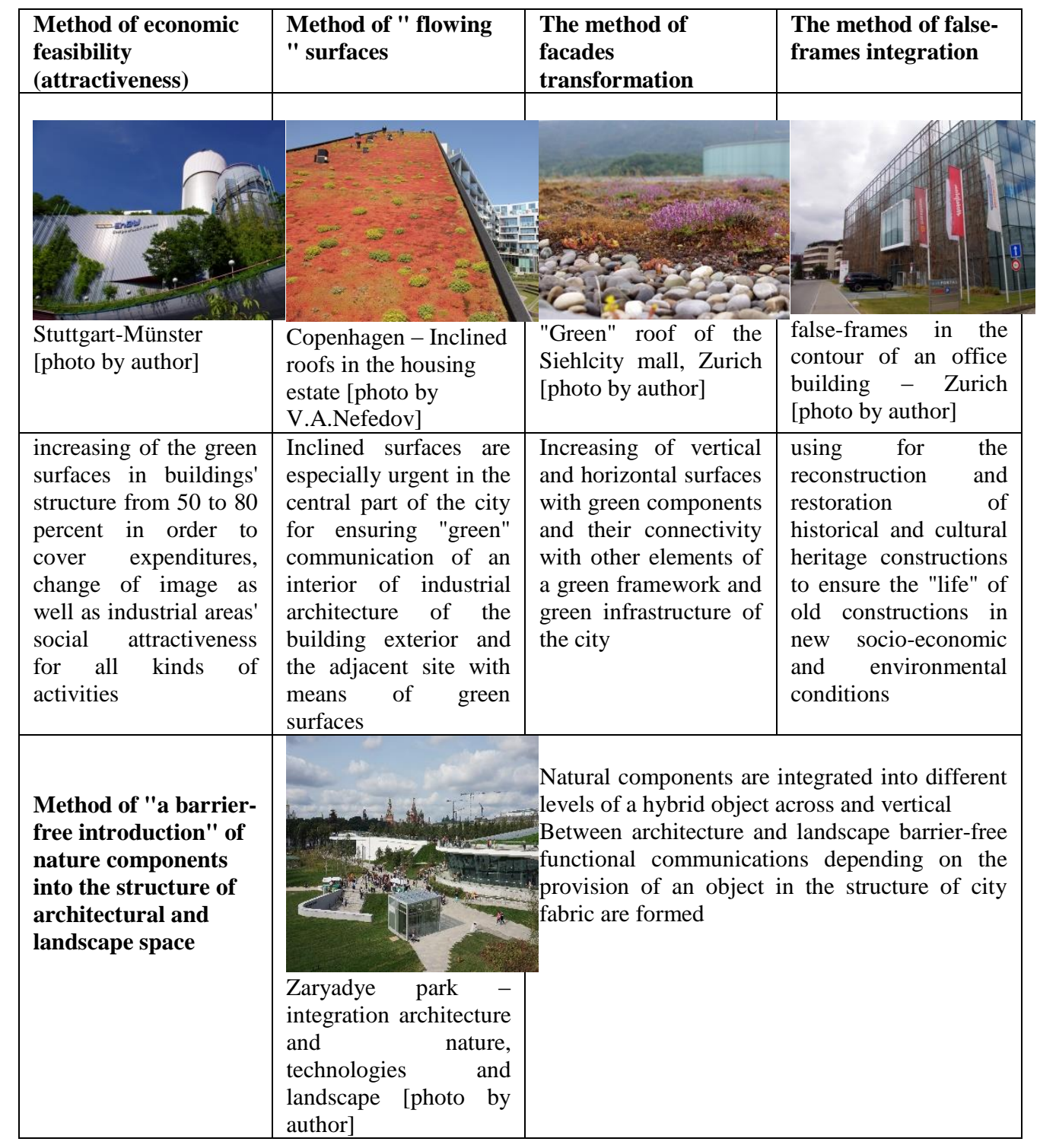

Method of "a barrier-free introduction" of nature components in structure of architectural and landscape space as Zaryadye park, opens to us in details that between architecture and landscape barrier-free functional communications depending on the provision of an object in structure of city fabric are formed. 


\section{Discussion}

The modern directions of world design clearly demonstrate the interest of experts in multipurpose objects. In such object each planning element has the function and natural communications both in an object, and out of it. In typological structure of such complexes landscape communications, modern technologies and planning characteristics of territories are in a new way integrated.

It is also necessary to note that in new projects there is a shift of emphases on the vertical communications of planning elements with natural components in a contour of a multipurpose object. And the most import of the space between buildings gives way to structure of a landscape with the disappearing "visible borders" between the building and city fabric.

\section{Conclusions}

The presented examples and their comparison with Zaryadye park show the new opportunities of association of the building with environment as regarding of updating design, transformation of front space with use of innovative technologies for saving energy, and on collecting rain water. At the same time on typological characteristics hybrid objects develop as model with public and reactionary, engineering and public and also inhabited and recreational properties.

In the formation of the concept of a multipurpose architectural and landscape hybrid object the emphasis on social and cultural programming, different typology and building architecture, integration of the nature components by means of new design technologies in front and landscape space for the purpose of dressing and dissolution of object borders in the urban environment is placed.

The uniqueness of each realized hybrid space is the basic principles of its organization consists of the expansion of inclusion ideas of saving energy technologies in a designing process of buildings and a surrounding landscape when change of the principles of landscape planning is the main condition of increase in stability of the urban environment.

Multipurpose architectural and landscape objects have new "flexibility" in relation to the cities and artificially created landscapes. The world practice showed that they can be compactly integrated into the central parts of the large cities where is the deficiency of extra-architectural space, and in the structure of the former urbanized territories for their renovation and maintenance of image of "the green city" is observed [6].

In this regard the term "sustainable development" habitual to experts gains the new sense as the resilient city with the steady environment and hybrid multipurpose objects means resistance to aggressive external influences through integration of new technologies of architectural and landscape design.

\section{References}

1. Appenzeller, M. Gietama, R. City regeneration today. TOPOS: The International Review of Landscape Architercture and Urban Design - 2010, № 73: Sustainability, 2010. - p 18-23.

2. Meyer, E. K.. River Park as a Place of Movement. TOPOS: The International Review of Landscape Architercture and Urban Design - 2014, № 89: Sustainability, 2014. - p 76-82. 
3. Arabianranta. Rethinking Urban Living. (City of Helsinki Urban Facts. City of Helsinki Economic and Planning Center. Art and Design City Helsinki Oy). - WS Bookwell Oy, Porvoo, 2007. - P. 288.

4. Farr, D. Sustainable Urbanism: Urban design with nature (2008) John Wiley \& Sons, Inc., $352 \mathrm{p}$.

5. Nannan, D. Zhang, L. Ruff, S. From Expo City to Sustainable City. TOPOS: The International Review of Landscape Architercture and Urban Design - 2010, № 70: Sustainability, 2010. - p 19-27.

6. Speech: Landshaft / landscape. - 2017. - №20. - C.272

7. Krasilnikova, E. Landscape Urbanism. Teoriya-Praktika: scientific monograph / Krasilnikova E.E. - Volgograd: LLC IAA Oblastnye vesti, 2015. P.1: scientific and practical bases of landscape urbanism [Text]. - 2015. - P. 156 (in Russian)

8. Nefedov, V. Urban landscape design. SPb, Luibavich - 2012. - 317 p. (in Russian)

9. Nefedov, V. How to return the city back to people. M.: Iskusstvo - XXI vек, 2015. 160 p.: ill. (in Russian)

10. Zaryadye. Booklet was published by the Committee for architecture and urban planning of Moscow, p.87, (2017)

11. Information on Fukuoka Prefectural International Hall http://www.greenroofs.com/projects/acros-fukuoka-prefectural-international-hall (2018)

12. Information on Bosco Verticale/Boeri Studio https://www.archdaily.com/777498/boscoverticale-stefano-boeri-architetti

13. Kongjian, Yu. DESIGNED ECOLOGIES: The Landscape Architecture of Kongjian Yu. Edited by William S. Saunders. Birkhaeuser, Bassel, 2012. - P. 255

14. Dreiseitl Herbert. BLUE-GREEN infrastructure for cities [Text]/ H.Dreiseitl // TOPOS: The International Review of Landscape Architercture and Urban Design - 2013, № 84: Urban Strategies, 2013. - p. 77-79.

15. Hentschel, A. Y How green will we live. Gruener wohnen / Green living [Text] / DEUTSCHER LANDSCHAFTSARCHITEKTUR-PREIS / GERMAN LANDSCAPE ARCHITECTURE PRIZE. -2011. - P. 32-52.

16. Vertical Landscape. Edited by Graham Cleary. 2014 by Design Media Publishing Limited. This edition published in September 2014, P. 255

17. Information on Stadthaus M1 https://www.archdaily.com/546225/stadthaus-m1barkow-leibinger

18. Information on Vinge Masterplan Proposal / EFFEKT + Henning Larsen Architects https://www.archdaily.com/376167/vinge-masterplan-proposal-effekt-henning-larson$\underline{\text { architects }}$ 